\title{
Development of the simultaneous detection of Ralstonia solanacearum race 3 and Clavibacter michiganensis subsp. sepedonicus in potato tubers by a multiplex real-time PCR assay
}

\author{
Sébastien Massart • Catherine Nagy • \\ M. Haissam Jijakli
}

Accepted: 12 September 2013 / Published online: 30 October 2013

(C) KNPV 2013

\begin{abstract}
Clavibacter michiganensis subsp. sepedonicus and Ralstonia solanacearum (Smith) Yabuuchi et al. race 3 are the causal agents of ring-rot and brown-rot of potato respectively. These diseases represent a serious threat to potato production in temperate climates. Both bacteria are listed as A2 pests in the EPPO region and as zero-tolerance quarantine organisms in the European Union. All the detection tests developed so far were only focused on the detection of a single pathogen while the absence of both bacteria has to be certified in the seed tubers. We have therefore developed a new multiplex real-time PCR assay to simultaneously detect both bacteria in a single assay. Additionally, the reliability of this molecular diagnostic test has been improved by the simultaneous amplification of an internal control, corresponding to a potato gene co-extracted from the sample. The polyvalence and the specificity of each set of bacterial primers and probes were evaluated on more than 90 bacterial strains. The limit of detection of this triplex real-time protocol was similar to those observed with other molecular protocols previously developed for the individual detection of one of these bacteria. A concordance of $100 \%$ was obtained in a blind test mimicking the routine application of the technology. In conclusion, this new protocol represents a straightforward and
\end{abstract}

S. Massart $(\bowtie) \cdot$ C. Nagy $\cdot$ M. H. Jijakli

Plant Pathology Laboratory, Gembloux Agro-Bio Tech (ULg), Passage des déportés, 2,

5030 Gembloux, Belgium

e-mail: sebastien.massart@ulg.ac.be convenient method potentially adapted to primary screening of potato tubers.

Keywords Ralstonia solanacearum $\cdot$ Clavibacter michiganensis $\cdot$ Real-time PCR · Diagnostic · Quarantine pathogen $\cdot$ Multiplex detection

\section{Introduction}

Clavibacter michiganensis subsp. sepedonicus and Ralstonia solanacearum (Smith) Yabuuchi et al. race 3 are the causal agents of ring-rot and brown-rot of potato respectively. These diseases represent a serious threat to potato production in temperate climates. Both bacteria are listed as A2 pests in the European and Mediterranean Plant Protection Organization (EPPO) region and zero-tolerance quarantine organisms in the European Union (EU). Within the EU, ring-rot or brown-rot outbreaks sporadically occurred, e.g. in Belgium (2003), Finland (2004), Ireland (2007) or United Kingdom (2012). These bacteria remain latent for a long time in asymptomatic potato tubers which are one of the main factors for the disease's dissemination (Ciampi et al. 1981; Zielke and Naumann 1984). The existing phytosanitary regulations rely on the availability of pathogen-free seed tubers.

The current official methods for individual detection of these bacteria in potato tubers are described in the EU directives 2006/56/CE (C. michiganensis subsp. sepedonicus) and 2006/63/CE ( $R$. solanacearum), 
respectively. In each state member, thousands of analyses are carried out each year on potato tubers. A primary screening test of a single pathogens can be made by immunofluorescence (IF) microscopy, conventional PCR, Fluorescence In Situ Hybridization (FISH) or selective isolation. Primary screening tests are specific for $R$. solanacearum or C. michiganensis sepedonicus detection. Once detected by two of these methods, the pathogen must be isolated and inoculated on eggplant to confirm pathogenicity.

The primary screening method should ideally be quick, sensitive and reliable but the current official testing procedures are quite labour intensive and time-consuming. Real-time PCR offers many advantages as a primary screening protocol: it is more rapid, sensitive and reproducible than PCR, it is well adapted to high throughput analysis and there is no post-PCR processing step (Mackay 2004; Mumford, et al. 2006). Real-time PCR reduces staff input and time, and lowers the risk of false-positive results due to carryover contamination. In previous studies, real-time PCR protocols using the TaqMan fluorescent chemistry methodology were developed for the single detection of R. solanacearum (Ozakman and Schaad 2003; Weller et al. 2000) or of C. michiganensis sepedonicus (Bach et al. 2003; Schaad et al. 1999).

Plant samples often contain PCR inhibitors, like acidic polysaccharides or phenolic compounds, which can hamper the PCR reaction and lead to false-negative results. The reliability of a molecular diagnostic test can be improved by the use of controls designed to test the quality of the extract and PCR reaction. The use of an internal control should be mandatory for a technique used by several laboratories and within quality assurance programs (Hoorfar et al. 2003). As a consequence, internal controls are very often incorporated in the realtime PCR methods developed to detect plant, animals or human pathogens (Baric and Dalla-Via 2004; Fernández-Pinero et al. 2013; Li et al. 2013; Van Brunschot et al. 2013). Internal control may correspond to a foreign DNA added to the sample or to DNA coextracted with the DNA target. For plant pathogen diagnostics, an internal control corresponding to the amplification of a plant gene co-extracted from the sample is recommended. The detection of the internal control will certify the absence of false-negatives due to PCR inhibition or nucleic acid extraction failure.

All the primary screening tests of the directive, as well as the real-time PCR protocols developed so far, were only focused on the detection of a single pathogen while the absence of both bacteria has to be certified in the seed tubers. As a consequence, separate tests have to be done on the same potato extract, which duplicate the time and labour necessary. In this context, a single assay which simultaneously detects $R$. solanacearum race 3 and $C$. michiganensis subsp. sepedonicus holds great interest.

In this paper, we describe the development of a multiplex real-time PCR protocol for the simultaneous detection of C. michiganensis subsp. sepedonicus and $R$. solanacearum race 3 in potato tubers. The reliability of this protocol has been improved by the amplification of a third DNA target consisting in an internal PCR control from potato chloroplastic DNA.

\section{Material and methods}

Biological material and growth media Strains used in this study and their source are described in Table 1. Strains of Ralstonia solanacearum and Clavibacter michiganensis subsp. sepedonicus were grown at $25^{\circ} \mathrm{C}$ on media 2 (Beef Extract, $1 \mathrm{~g} \mathrm{l}^{-1}$; Yeast extract, $2 \mathrm{~g} \mathrm{l}^{-1}$, Peptone, $5 \mathrm{~g} \mathrm{l}^{-1} ; \mathrm{NaCl}, 5 \mathrm{~g} \mathrm{l}^{-1}, \mathrm{KH}_{2} \mathrm{PO}_{4}$, $0.45 \mathrm{~g} \mathrm{l}^{-1} ; \mathrm{Na}_{2} \mathrm{HPO}_{4} .2 \mathrm{H}_{2} \mathrm{O}, 2.39 \mathrm{~g} \mathrm{l}^{-1}$; Agar $15 \mathrm{~g} . \mathrm{l}^{-1}$ ) and 39 (Glucose, $10 \mathrm{~g} \mathrm{l}^{-1}$; Yeast extract, $5 \mathrm{~g} \mathrm{l}^{-1}$; Peptone, 5 g. $^{-1}$; Casein hydrolisate $0.1 \mathrm{~g} \mathrm{l}^{-1}$ and Agar $15 \mathrm{~g} \mathrm{l}^{-1}$ ), respectively. $R$. solanacearum and $C$. michiganensis are two quarantine pathogens in Europe, the bacterial growth and the DNA extraction were therefore carried out in the quarantine laboratory (L2Q). The other bacterial strains were cultured at $25{ }^{\circ} \mathrm{C}$ on $\mathrm{LB}$ medium (Triptone $10 \mathrm{~g} \mathrm{l}^{-1}$, Yeast extract, $5 \mathrm{~g} \mathrm{l}^{-1}$; $\mathrm{NaCl}$, $10 \mathrm{~g} \mathrm{l}^{-1}$ ). Sixteen commercially available potato varieties were tested in this study: 'anosta', 'bintje', 'charlotte', 'chocolat', 'chypre', 'cleopatra', 'franceline', 'gasoré', 'majestic', 'marfona', 'Mona Lisa', 'nicolas', 'primura', 'rosabelle', 'shepody' and 'spunta'.

Sample preparation and DNA extraction The sample preparation protocol mimicked the official protocol described in the EU Directives 2006/56/CE and 2006/63/CE. For each sample, 20 potato tubers were washed with tap water to remove adherent soil. A small core of tuber containing vascular tissue was removed near the stolon end of each tuber. The 20 cores were placed in a plastic bag. Four milliliters of PBS buffer $(0.05 \mathrm{M})+$ PVP $40(5 \%)$ were added. The sample was 
Table 1 Bacterial strains used in this study

Species
Ralstonia solanacearum (biovar - race)
$(1-1)$
$(2-3)$

$\mathrm{N}^{\circ}$ of

strains

4

54

Strains

$(3-1)$

$(4-1)$

$(5-5)$

Clavibacter michiganensis

subsp. sepedonicus

subsp. nebraskensis

subsp. michiganensis

subsp. tessalarius

Xanthomonas campestris

pv. Pelargonii

Pseudomonas fluorescens

P. marginalis ssp marginalis

P. syringae subsp. morsprunorum

P. syzygii

R. picketii

Ralstonia sp.

Peptobacterium chrysanthemi

P. carotovorum subsp. carotovorum

P. atrosepticum

Banana Blood bacterial disease

Pantoea agglomerans

Burkholderia cepacia
NCPPB $325 \mathrm{~T}^{\mathrm{US}}, 3967^{\mathrm{Br}}$

DGBBC 708, 709

DGBBC $502^{\mathrm{B}}, 504^{\mathrm{B}}, 505^{\mathrm{B}}, 507^{\mathrm{B}}, 515^{\mathrm{B}}$, $519^{\mathrm{B}}, 521^{\mathrm{B}}, 539^{\mathrm{B}}, 550^{\mathrm{B}}, 569^{\mathrm{B}}, 665^{\mathrm{B}}$, $667^{\mathrm{B}}, 668^{\mathrm{B}}, 669^{\mathrm{B}}, 670^{\mathrm{B}}, 671^{\mathrm{B}}, 675^{\mathrm{B}}$, $679^{\mathrm{B}}, 680^{\mathrm{B}}, 681^{\mathrm{B}}, 682^{\mathrm{B}}, 683^{\mathrm{B}}, 729^{\mathrm{K}}$, $730^{\mathrm{K}}, 731^{\mathrm{K}}, 732^{\mathrm{K}}, 1110^{\mathrm{B}}, 1111^{\mathrm{B}}$, $1112^{\mathrm{B}}, 1287^{\mathrm{B}}, 1181^{\mathrm{B}}$

LMG $2294^{\mathrm{Co}}, 2298^{\mathrm{Co}}, 2300^{\mathrm{Is}}, 17139^{\mathrm{Cy}}$, $17140^{\mathrm{Sw}}, 17141^{\mathrm{TN}}, 17142^{\mathrm{UK}}$

NCPPB $1584^{\mathrm{Cy}}, 2505^{\mathrm{Sw}}, 3857^{\mathrm{UK}}, 3989^{\mathrm{Br}}$, $4028^{\mathrm{Co}}, 4153^{\mathrm{Eg}}, 4154^{\mathrm{T}}, 4156^{\mathrm{N}}, 4157^{\mathrm{F}}$, $4158^{\mathrm{Po}}, 4160^{\mathrm{Sp}}$,

PD $2140^{\mathrm{LR}}, 2778^{\mathrm{TN}}$,

R $578^{\mathrm{Pe} *}, \mathrm{R} 568^{\mathrm{Br} *}$

LNPV $946^{\mathrm{F}}$

NCPPB $3996^{\mathrm{Pe}}, 3997^{\mathrm{A}}$

NCPPB $4005^{\mathrm{Ph}}, 4029^{\mathrm{SL}}$

NCPPB $4012^{\mathrm{Ch}}$

LMG $2889^{\mathrm{Ca}}, 2893^{\mathrm{Ca}}, 2899^{\mathrm{US}}, 2901^{\mathrm{US}}$, $5842^{\mathrm{D}}, 5845^{\mathrm{TN}}, 5854^{\mathrm{F}}, 5861^{\mathrm{Sw}}, 5875^{\mathrm{G}}$, $5876^{\mathrm{G}}, 6317^{\mathrm{G}}, 6385^{\mathrm{N}}, 6717^{\mathrm{Fi}}$

DGBBC $214^{\mathrm{G}}, 227^{\mathrm{B}}, 228^{\mathrm{B}}, 229^{\mathrm{B}}, 232^{\mathrm{B}}$, $234^{\mathrm{B}}, 239^{\mathrm{B}}, 240^{\mathrm{B}}, 241^{\mathrm{B}}, 254^{\mathrm{G}}$

LMG 3700

LMG 7333

PD 336

N.D.

N.D.

LMG2210

LMG5463

LMG 10662

Pr 1150, N.D.

NCPPB $3856^{\mathrm{UK}}$

LMG 2544

N.D.

N.D.

NCPPB 3726

CPA-2 ${ }^{\mathrm{Sp}}$

NCPPB $945^{\mathrm{UK}}$ centrifuged at $16,000 \times g$ during $10 \mathrm{~min}$. The pellet was further resuspended in $100 \mu \mathrm{l}$ of PBS 1X. The protocol of the EasyDNA kit (LifeTechnologies) was followed thoroughly macerated during 2-3 min using a Homex (Bioreba, Reinach, Switzerland). The macerate was centrifuged at $200 \times \mathrm{g}$ for $10 \mathrm{~min}$. The supernatant was 
with slight modifications. First, solution A $(350 \mu \mathrm{l})$ was added to the cell suspension or potato macerate. After slight vortexing, the mix was incubated at $90{ }^{\circ} \mathrm{C}$ during 15 min. Solution B $(150 \mu \mathrm{l})$ was further added and the mix was vigorously vortexed until the sample was uniformly viscous. Five hundred microlitre of chloroform were added and the sample was vortexed until homogenization. After a centrifugation step at maximum speed during $15 \mathrm{~min}$ at $4{ }^{\circ} \mathrm{C}$, the upper phase was transferred to a fresh microcentrifuge tube for ethanol precipitation and slightly vortexed. The tube was incubated $30 \mathrm{~min}$ on ice and centrifuged at maximum speed at $4{ }^{\circ} \mathrm{C}$ during 5 min. The pellet was washed with $80 \%$ ethanol, centrifuged and further resuspended in $100 \mu \mathrm{l}$ of TE buffer. Two microlitre of a $2 \mathrm{mg} \mathrm{ml}^{-1} \mathrm{RNase}$ were added before an incubation of $30 \mathrm{~min}$ at $37^{\circ} \mathrm{C}$. The extract was conserved at $4{ }^{\circ} \mathrm{C}$ (short-time) or at $-20^{\circ} \mathrm{C}$ (long-time). The DNA concentration was adjusted at $10 \mathrm{ng}$ per PCR reaction during polyvalence and specificity assessment of the PCR protocol.

Selection of primers and probes New specific primers and probes (Table 2) were selected to fit the recommendations for multiplex real-time PCR (Qiagen Handbook, Qiagen). For both bacteria, the primers and probes were selected in the rRNA gene intergenic spacer sequences. Six sequences extracted from the NCBI database (accession $\mathrm{n}^{\circ}$ L43095, U09378, U09379, U09380, U09381, U09382) were aligned for $C$. michiganensis subsp. sepedonicus. For $R$. solanacearum race 3, 31 sequences were aligned: 11 sequences obtained during our work (unpresented results, NCBI accession $n^{\circ}$ EF523221 to EF523231) and 20 sequences from the NCBI database (from aj277767 to aj277777; aj783972; from aj277849 to aj277856; and ay847456) were aligned. For the internal control, 13 sequences of the chloroplastic ATP synthase beta-subunit from $S$. tuberosum (DQ231562, DQ386163, AY300043), S. nodiflorum (AJ235604), S. bulbocastanum (DQ347958), Lycopersicum esculentum (AM097200, AJ236183), Nicotiana sylvestris (AB237912), N. tomentosiformis (AB240139), N. plumbaginefolia (X61320) and N. tabacum (X61319, AF035909, Z00044) were aligned. The sequence alignments were made using the DNAMAN software 5.2.2 (Lynnon Biosoft, Vaudreuil-Dorion, Canada). The primers and the Minor Groove Binder (MGB) probe of each DNA target were selected using the software PrimerExpress 5.1 (Applied Biosystem, Forster City, USA). The primers were supplied by Eurogentec (Liège, Belgium). The MGB probes were supplied by Applied Biosystem with a 5' covalently attached reporter dye (FAM, VIC or NED), a nonfluorescent quencher and MGB moiety at the $3^{\prime}$ end.

PCR amplification Real-time PCR was performed in $25 \mu$ volumes containing 1X QuantiTect Multiplex PCR Master Mix (Qiagen), $1 \mu$ l of each primer pair, $1 \mathrm{ul}$ of each probe, $5 \mu \mathrm{l}$ of DNA template and PCRgrade water to get a final volume of $25 \mu$. The thermal cycle consisted of a denaturation step of $95{ }^{\circ} \mathrm{C}$ for $15 \mathrm{~min}$ followed by 35 cycles of $95{ }^{\circ} \mathrm{C}$ for $20 \mathrm{~s}$ and $60{ }^{\circ} \mathrm{C}$ for $60 \mathrm{~s}$. The amplifications were carried out on the ABI Prism 7900 SDS (Life Technologies) and the results were analyzed by the Sequence Detection System 2.1 (Life Technologies). The polyvalence and specificity of each primer pair and probe was tested individually using a final concentration of $1 \mu \mathrm{M}$ for the primers and $0.2 \mu \mathrm{M}$ for the probe. The multiplexing conditions were optimized by evaluating several primer and probe concentrations for each target according to the following steps: (i) primer concentration $(1,000$
Table 2 Primers and probes used in this study

${ }^{a} F$ forward, $R$ reverse, $P$ probe

\begin{tabular}{llll}
\hline Primer or probe $^{\mathrm{a}}$ & Sequence $\left(5^{\prime}-3^{\prime}\right)$ & Length $(\mathrm{nt})$ & Dye \\
\hline MultiRaso-F & CGCGGAGCATTGATGAGAT & 19 \\
MultiRaso-R & TCGTAATACTGGTTGATACAATCACAAC & 28 & \\
MultiRaso-P & CTCGCAAAAACGC & 13 & \\
MultiClav-F & TGGTTTCTTGTCGGACCCTTT & 21 & VIC \\
MultiClav-R & CGTCCACTGTGTAGTTCTCAATATACG & 27 & \\
MultiClav-P & CGTCGTCCCTTGAGTGG & 17 & FAM \\
MultiPot-F & GGTTTCGTAATGTTCCTCACCAA & 23 & \\
MultiPot-R & AAAGGTATTTATCCAGCAGTAGATCCTT & 28 & NED \\
MultiPot-P & CATGGTTGACGTTGAAT & 17 & \\
\hline
\end{tabular}


$\mathrm{nM}, 500 \mathrm{nM}$ and $300 \mathrm{nM}$ ) for both pathogens without internal control, (ii) probe concentration $(100 \mathrm{nM}$ and $50 \mathrm{nM}$ ) for both pathogens without internal control, and (iii) primer concentration (900 $\mathrm{nM}$ and $300 \mathrm{nM})$ for the internal control alone and in triplex detection with both pathogens.

Effect of potato macerate To evaluate the effect of inhibitors from potato macerate, the same bacterial quantity $\left(100 \mu \mathrm{l}\right.$ at $\left.1.510^{5} \mathrm{cfu} \mathrm{m}^{-1}\right)$ was added to $3 \mathrm{ml}$ of PBS buffer or to $3 \mathrm{ml}$ of potato macerate just before centrifugation at $200 \times g$ during $10 \mathrm{~min}$. Genomic DNA from both conditions was extracted and subjected to PCR amplification in duplicate. Three independent repetitions of this assay were carried out.

Limit of detection Bacterial suspensions were serially diluted by 10 -fold dilution. Hundred microliters of each dilution were added to the plastic bag containing the potato macerate as describe here above. The cfu number of the suspension was estimated by plating on corresponding medium. The macerate was further subjected to DNA extraction. The limit of detection for both bacteria was evaluated from two independent DNA extractions, each amplified in duplicate twice independently.

Blind validation of the protocol Four tuber extracts naturally contaminated by $R$. solanacearum or $C$. michiganensis sepedonicus were sent by the Institute for Agricultural and Fisheries Research (ILVO, Dr. Johan Van Vaerenbergh), the official phytosanitary certification laboratory in Belgium. These samples were sent coded to ensure a blind test. These tubers extracts were crushed as described above and analyzed alone or after dilution in 199 volumes of juice from healthy tubers. This dilution aimed to mimic the presence of a unique infected tuber in the sampling of a potato batch, fixed at 200 tubers per batch by the EU directives. In a second blind test, 40 composite samples (20 potato macerates sent in duplicate) from 200 seed potato tubers, prepared as described in the EU directives 2006/56/CE and 2006/63/CE, were sent by ILVO. Known amounts of $R$. solanacearum or C. michiganensis sepedonicus cells were picked in some samples by ILVO. The samples were coded by ILVO to ensure a blind test. For both experiments, the protocol of sample preparation, DNA extraction and triplex real-time PCR was applied. All the DNA extracts were amplified in duplicate twice independently.

\section{Results}

Polyvalence and specificity For each set of bacterial primers and probe, the protocol was tested on a strain collection including species commonly isolated from potato tubers and species genetically related to $R$. solanacearum race 3 or $C$. michiganensis subsp. sepedonicus. The MultiRaso primers and probe successfully detected the 52 strains of $R$. solanacearum race 3 biovar 2 and the two strains of biovar $2 \mathrm{~T}$ tested in this study. These strains were isolated from potato or pelargonium from very diverse locations in the world (Table 1). A fluorescent signal was also obtained with the four strains of $R$. solanacearum race 1 biovar 1 isolated from potato or L. esculentum. No fluorescent signal was obtained with the other bacterial strains. All the 23 strains of $C$. michiganensis subsp. sepedonicus used in this study were detected by the MultiClav primers and probe. No fluorescent signal was obtained from all the other bacterial strains listed in Table 1 except the strain of $C$. michiganensis subsp. tessalarius. Purified DNA from Solanum sp. samples was also tested with MultiRaso and MultiCms primers and probes to discard false-positive results from healthy material. Genomic DNA from 16 potato varieties was subjected to real-time PCR to evaluate the polyvalence of the Multipot primers and probe. A positive signal was observed for all these varieties.

Optimization of primer concentration The optimal primer and probe concentrations for simultaneous detection of both pathogens were experimentally determined by performing PCR on samples containing both bacteria at either high $\left(2.5 \times 10^{5} \mathrm{cfu} / \mathrm{PCR}\right)$ or low $(100 \mathrm{cfu} / \mathrm{PCR})$ cfu. The primer concentration was optimized at $300 \mathrm{nM}$ for each primer pair and the optimal probe concentration corresponded to $100 \mathrm{nM}$ for both probes. As exposed in Table 3, a higher Ct value was observed for the pathogen at 100 cfu per PCR when combined with $2.5 \times 10^{5}$ cfu per PCR of the other pathogen. For the internal control, we selected the lowest tested concentration of primers and probes, e.g. $300 \mathrm{nM}$ of each primer and $250 \mathrm{nM}$ of the probe, ensuring a $\Delta \mathrm{Rn}$ of at least 0.6. This minimal fluorescence level is required to allow automatic calculation of the threshold for each sample (Life Technologies, personal communication).

Effect of potato macerate Equal amounts of $R$. solanacearum and C. michiganensis sepedonicus cells 
Table 3 Effect of probe concentration on the detection of $R$. solanacearum (Raso) and C. michiganensis subsp. sepedonicus (Clavi)

\begin{tabular}{|c|c|c|c|c|}
\hline \multirow[b]{2}{*}{ Probe concentration } & \multicolumn{2}{|c|}{ R. solanacearum detection $\mathrm{Ct} \pm \mathrm{S}_{\mathrm{r}}{ }^{\mathrm{a}}$} & \multicolumn{2}{|c|}{ C. michiganensis sepedonicus detection $\mathrm{C} t \pm \mathrm{s}_{\mathrm{r}}{ }^{\mathrm{a}}$} \\
\hline & $100 \mathrm{nM}$ & $50 \mathrm{nM}$ & $100 \mathrm{nM}$ & $50 \mathrm{nM}$ \\
\hline $\mathrm{R}_{\mathrm{L}} \mathrm{C}_{\mathrm{L}}$ & $29.1 \pm 0.8$ & $29.87 \pm 0.4$ & $30.5 \pm 0.1$ & $30.9 \pm 0.4$ \\
\hline $\mathrm{R}_{\mathrm{H}} \mathrm{C}_{\mathrm{L}}$ & $20.8 \pm 0.5$ & $20.9 \pm 0.9$ & $32.3 \pm 0.0$ & $32.4 \pm 1.7$ \\
\hline $\mathrm{R}_{\mathrm{L}} \mathrm{C}_{\mathrm{H}}$ & $30.7 \pm 0.2$ & $31.3 \pm 0.2$ & $22.5 \pm 1.9$ & $23.1 \pm 1.6$ \\
\hline $\mathrm{R}_{\mathrm{H}} \mathrm{C}_{\mathrm{H}}$ & $21.0 \pm 1.0$ & $22.5 \pm 1.1$ & $22.8 \pm 0.6$ & $23.3 \pm 1.0$ \\
\hline
\end{tabular}

The samples names correspond to: $\mathrm{R}_{\mathrm{L}} \mathrm{C}_{\mathrm{L}}: 100$ cfu of Raso and 100 cfu of Clavi per PCR; $\mathrm{R}_{\mathrm{H}} \mathrm{C}_{\mathrm{L}}: 2.5 \times 10^{5}$ cfu of Raso and 100 cfu of Clavi per PCR; $\mathrm{R}_{\mathrm{L}} \mathrm{C}_{\mathrm{H}}: 100$ cfu of Raso and $2.5 \times 10^{5}$ cfu of Clavi per PCR; $\mathrm{R}_{\mathrm{H}} \mathrm{C}_{\mathrm{H}}: 2.5 \times 10^{5}$ cfu of Raso and $2.5 \times 10^{5}$ cfu of Clavi per PCR

${ }^{\text {a }}$ Average $\mathrm{Ct}$ and standard deviation $\left(\mathrm{s}_{\mathrm{r}}\right)$ values calculated for two independent amplifications each in triplicate

were subjected to DNA extraction and PCR amplification in presence or absence of potato macerate. The results presented in Table 4 showed that the presence of potato macerate did not significantly influence the detection of both bacteria.

Limit of detection The limit of detection of the duplex and the triplex protocols were evaluated simultaneously. Both protocols reproducibly detected at least $100 \mathrm{cfu} / \mathrm{ml}$ of potato macerate for each bacterium (corresponding to $20 \mathrm{cfu}$ per PCR reaction). The coamplification of the internal control did not modify the level of detection for both bacteria.

Validation of the protocol by two blind tests The multiplex protocol was applied on four potato tubers naturally infected by $R$. solanacearum or $C$. michiganensis subsp. sepedonicus. The bacteria were successfully detected in the samples containing the infected tuber alone or mixed with 199 healthy tubers (Table 5). No sample was inhibitory as the internal control was always amplified. The multiplex protocol was also applied on the 40 samples sent in two batches by the Belgian official certification laboratory (ILVO, Dr. J. Van Vaerenbergh). The Ct value of the internal control ranged between 22.6 and 28.1, indicating that the target DNA was abundant in the

Table 4 Effect of potato macerate on the detection of $R$. solanacearum and C. michiganensis subsp. sepedonicus

\begin{tabular}{lll}
\hline Bacterial species & $\begin{array}{l}\text { W/o potato } \\
\text { macerate } \mathrm{Ct} \pm \mathrm{S}_{\mathrm{r}}{ }^{a}\end{array}$ & $\begin{array}{l}\text { With potato } \\
\text { macerate } \mathrm{C} t \pm \mathrm{s}_{\mathrm{r}}\end{array}$ \\
\hline R. solanacearum & $24.1 \pm 1.1$ & $24.6 \pm 0.7$ \\
C. michiganensis sepedonicus & $25.5 \pm 1.3$ & $25.9 \pm 0.8$ \\
\hline
\end{tabular}

${ }^{a}$ Average $\mathrm{Ct}$ and standard deviation $\left(\mathrm{s}_{\mathrm{r}}\right.$ ) values calculated for two independent extraction each amplified twice in triplicate samples. No fluorescent signal of the internal control was observed for only one replicate for two samples (two inhibitions on 160 PCR reactions). An additional PCR was done for these two samples and the internal control was successfully amplified in all the replicates. An inhibition of the internal control amplification was observed in only $1 \%$ of the PCR reactions during this validation. The new real-time protocol successfully detected the bacteria in all the spiked samples, e.g. 8 samples spiked by $R$. solanacearum, 8 samples spiked by $C$. michiganensis subsp. sepedonicus and 8 samples with double contamination. The bacteria were not detected in any of the 16 healthy samples. Identical conclusions were always obtained with both replicates of each macerate. A $100 \%$ concordance was therefore obtained between the status of the 44 blinded samples and the results of the realtime PCR.

\section{Discussion}

In this study, we developed and optimized an internally controlled real-time PCR assay for the simultaneous detection of $R$. solanacearum race 3 and $C$. michiganensis subsp. sepedonicus, two quarantine pathogen bacteria of potato in Europe. This is the first method allowing the simultaneous detection of both bacteria in a single assay with an internal control from potato. Up to now, the recommended methods were focused on the individual detection of $C$. michiganensis subsp. sepedonicus or $R$. solanacearum.

$R$. solanacearum race 3 (equivalent to biovar $2 \mathrm{~A}$ and $2 \mathrm{~T}$ ) is adapted to temperate climates and is responsible for recent outbreaks of potato brown-rot in several countries of Western Europe and other temperate climates. The 
Table $5 \mathrm{Ct}$ values obtained with the new real-time multiplex protocol during practical application on infected tubers (part of the blindtest)

\begin{tabular}{lllll}
\hline Sample & Internal control Ct $\pm \mathrm{s}_{\mathrm{r}}{ }^{\mathrm{a}}$ & R. solanacearum $\mathrm{Ct} \pm \mathrm{S}_{\mathrm{r}}$ & C.m. sepedonicus $\mathrm{Ct} \pm \mathrm{S}_{\mathrm{r}}$ & Rtatus \\
\hline 1 & $22.6 \pm 0.7$ & $12.4 \pm 0.3$ & n.s. & Raso \\
$1(1: 200)^{\mathrm{d}}$ & $22.3 \pm 0.3$ & $21.1 \pm 0.3$ & $13.5 \pm 0.3$ & Raso \\
2 & $20.1 \pm 0.1$ & n.s. & $21.6 \pm 0.1$ & Clav \\
$2(1: 200)$ & $22.0 \pm 0.2$ & n.s. & n.s. & Clav \\
3 & $21.7 \pm 0.4$ & $15.0 \pm 0.1$ & n.s. & Raso \\
$3(1: 200)$ & $22.8 \pm 0.3$ & $23.5 \pm 0.2$ & $14.5 \pm 0.5$ & Raso \\
4 & $23.9 \pm 0.3$ & n.s. & $21.0 \pm 0.1$ & Clav \\
$4(1: 200)$ & $23.9 \pm 0.2$ & n.s. & Clav \\
\hline
\end{tabular}

${ }^{\text {a }}$ Average $\mathrm{Ct}$ value and standard deviation $\left(\mathrm{s}_{\mathrm{r}}\right)$ calculated on two runs with two replicates per sample

${ }^{\mathrm{b}}$ Status of the sample (known a posteriori): Raso, presence of $R$. solanacearum; Clav, presence of C. michiganensis sepedonicus

${ }^{\mathrm{c}}$ n.s. no fluorescent signal

d (1:200): one naturally infected tuber mixed with 199 healthy tubers

main objective of our work was to detect all the strains of $R$. solanacearum race 3 potentially infecting and devastating potato crops in temperate climates. During our assays, 52 strains of race 3 (biovar 2A and $2 \mathrm{~T}$ ) isolated from worldwide locations were successfully detected. Additionally, the PCR protocol also detected strains belonging to biovar 1 . These 3 biovars correspond to subdivision 2A. The specificity of detection is similar to those obtained by Rs-1-F/Rs-1-R primers (Pastrik et al. 2002), one of the official primary screening PCR methods. In our case, this level specificity of detection was mainly brought by the forward primer and the probe. The MGB probe presents a perfect match with all the sequences from biovar $2 \mathrm{~A}$ and $2 \mathrm{~T}$ strains and a single mismatch (e.g. C/A at position 8) with biovar 1 strains. Thus, this single mismatch is tolerated by our PCR conditions. While some authors underlined the ability of TaqMan and TaqMan-MGB probes to discriminate single nucleotide polymorphism (Massart et al. 2005; Van Hoeyveld et al. 2004), other studies showed that TaqMan-MGB probes may tolerate up to two mismatches (Yao et al. 2006). The protocol detected the 23 strains of $C$. michiganensis subsp. sepedonicus and the tested strain of C. michiganensis subsp. tessalarius whose sequence presents a single mismatch with the TaqMan-MGB probe. $C$. michiganensis subsp. tessalarius causes mosaic-like syndrome on wheat and is specific to this plant species while it also attacks triticale (Fucikovsky and Duveiller 1997). It is therefore unlikely that $C$. michiganensis subsp. tessalarius could provoke false positive results in potato samples. More importantly, the specificity of the diagnostic protocol towards $R$. solanacearum or C. michiganensis spp. sepedonicus was assessed on ecologically related bacteria. No fluorescent signal were observed with other bacteria species infecting potato tubers (Peptobacterium spp., Xanthomonas spp.,...) and with the healthy samples from the 16 tested potato varieties.

The development of a PCR multiplex assay, allowing simultaneous detection of several DNA targets in a single amplification, is often complex and challenging. Interference and (or) competition between the individual amplifications have to be avoided (James et al. 2006). In this paper, the primers and probes were designed to function under identical PCR conditions and to avoid primer-dimer formation. Interference and competition between individual amplifications were always monitored by comparing the $\mathrm{Ct}$ obtained with or without multiplexing for each primer pair.

Inhibition of PCR reaction has previously been reported in potato extracts (Arulappan et al. 1996; Elphinstone et al. 1996). Pastrik and Maiss (2000) developed a DNA extraction protocol greatly limiting the PCR inhibition. Nevertheless, this protocol required numerous steps. We simplified it by eliminating the lysozyme digestion step and by directly processing the sample with the kit reagent and protocol. The only modification was the incubation of $15 \mathrm{~min}$ at $90{ }^{\circ} \mathrm{C}$, instead of $10 \mathrm{~min}$ at $65^{\circ} \mathrm{C}$ with the solution A (lysis buffer). This simplification of the protocol saved time and reagent while reaching the detection level previously obtained with $R$. solanacearum (Pastrik and Maiss 2000) and C. michiganensis sepedonicus (Pastrik 2000). Moreover, to certify the absence of 
inhibition for each sample, we developed an internal control based on the sequence of the chloroplastic gene of ATP synthase beta-subunit which is remarkably conserved within Solanum tuberosum species and the Solanaceae family.

A major limitation to the application of PCR-based diagnostic techniques in certification laboratories is the occurrence of false negatives due to PCR inhibitors, PCR reagents or thermal cycler dysfunction (Abu Al-Soud and Rådström 1998; Malorny et al. 2004). The inclusion of an internal control can identify any inhibition but a competitive amplification effect can occur with the other DNA targets. It is well-known that large amount of one target can inhibit the amplification of the other targets (Boivin et al. 2004). During our experiments, and after careful optimization of primer and probe concentrations, the detection sensitivity for both bacteria was not modified by the addition of the internal control

For quarantine pathogens such as $R$. solanacearum and $C$. michiganensis spp. sepedonicus, a crucial aspect in the design of molecular diagnostic methods is achieving a low detection level. This is particularly important as both bacteria can survive latently in infected seed tubers. The multiplex real-time PCR assay detected 100 cfu of $C$. michiganensis subsp. sepedonicus or $R$. solanacearum per $\mathrm{ml}$ of potato macerate. These levels are 10X and 100X lower than the requested level of sensitivity for an official detection method $\left(10^{3}-10^{4} \mathrm{cfu} \mathrm{ml}^{-1}\right)$. Furthermore, they are similar to those observed with other PCR or real-time PCR protocols developed for the individual detection of $R$. solanacearum or $C$. michiganensis sepedonicus (Pastrik 2000; Pastrik et al. 2002; Pastrik and Maiss 2000; Seal et al. 1999). When a high amount of one pathogen $\left(2.5 \times 10^{5} \mathrm{cfu} / \mathrm{PCR}\right)$ was combined with a low amount of the other pathogen ( $100 \mathrm{cfu} / \mathrm{PCR})$, a higher $\mathrm{Ct}$ was observed with the latter one. This phenomenon, commonly observed in multiplex tests, can be due to competition for reagents. This result means that the LOD for a pathogen can be modified by the presence of large amounts of the other pathogen. Even if this is theoretically possible, the probability of mixed infection of both pathogens is extremely low as their respective prevalence in potato seed is very low. Moreover, to our knowledge, there was no report of mixed infection to date. Nevertheless, even in a worst case scenario corresponding to a mixed infection with very high amount of one pathogen and low amount of the other one, the repeatable detection of at least $100 \mathrm{cfu} / \mathrm{PCR}$ is still achieved, e.g. $2 \mathrm{X}$ to $20 \mathrm{X}$ lower than the requested level of sensitivity for an official detection method.

A $100 \%$ concordance was observed between the results obtained by the new real-time protocol and the status of the 44 samples sent in blind by the official certification laboratory. More importantly, this protocol was also able to detect a single naturally infected tuber mixed with 199 healthy tubers. The Ct values of these composite samples ranged between 21.1 and 23.5, confirming the high sensitivity of this protocol to detect any of the bacteria from a single infected tuber.

In conclusion, this original real-time PCR protocol represents a straightforward and convenient method adapted to primary screening for tuber certification. As a next step, the adoption of a methodology as a new diagnostic test must rely on its inter-laboratory evaluation (Massart et al. 2008). Therefore, before any application in routine setting, an inter-laboratory evaluation of this protocol should be carried out to evaluate its robustness and performances in various certification laboratories.

Acknowledgments We thank Dr. Johan Van Vaerenbergh and Dr. Rachid Tahzima (ILVO, Gent, Belgium) for fruitful collaboration and for sending the blinded samples. We are grateful to Sylvie Van Mellaert for excellent technical assistance. We also thank MM. Walter Van Ormelingen et David Michelante from the Federal Agency for the safety of the Food Chain (AFSCA Belgium) for the external coordination of the blind-test and for fruitful discussions throughout the project. This work was supported by AFSCA and the General Management of Agriculture (DGA) of the Walloon Region Ministry (Belgium).

\section{References}

Abu Al-Soud, W., \& Rådström, P. (1998). Capacity of nine thermostable DNA polymerases to mediate DNA amplification in the presence of PCR-inhibiting samples. Applied and Environmental Microbiology, 64(10), 3748-3753.

Arulappan, F. X., van Beuningen, A. R., Derks, J. H. J., Wullings, B., Tjou-Tam-Sin, N. N. A., \& Janse, J. D. (1996). Comparison of the indirect and direct immunofluorescence test for the detection of latent brown rot infection, with a new antiserum. Annual report of the Plantenziektenkundige dienst, Diagnostic center (pp. 6). Wageningen, The Netherlands.

Bach, H. J., Jessen, I., Schloter, M., \& Munch, J. C. (2003). A TaqMan-PCR protocol for quantification and differentiation of the phytopathogenic Clavibacter michiganensis subspecies. Journal of Microbiological Methods, 52(1), 85-91. doi:10.1016/S0167-7012(02)00152-5. 
Baric, S., \& Dalla-Via, J. (2004). A new approach to apple proliferation detection: a highly sensitive real-time PCR assay. Journal of Microbiological Methods, 57(1), 135-145.

Boivin, G., Côté, S., Déry, P., De Serres, G., \& Bergeron, M. G. (2004). Multiplex real-time PCR assay for detection of influenza and human respiratory syncytial viruses. Journal of Clinical Microbiology, 42(1), 45-51.

Ciampi, L., Sequeira, L., \& French, E. R. (1981). Pseudomonas solanacearum. Distribution in potato plants and the establishment of latent infections. In C. Lozano (Ed.), Proceedings of the 5th International Conference on Plant Pathogenic Bacteria (pp. 148-161). Cali, Colombia: Centro Internacional de Agricultura Tropical.

Elphinstone, J. G., Hennessy, J., Wilson, J. K., \& Stead, D. E. (1996). Sensitivity of different methods for the detection of Ralstonia solanacearum in potato tuber extracts. EPPO Bulletin, 26, 15.

Fernández-Pinero, J., Gallardo, C., Elizalde, M., Robles, A., Gómez, C., Bishop, R., \& Arias, M. (2013). Molecular diagnosis of African swine fever by a new real-time PCR using universal probe library. Transboundary and Emerging Diseases, 60(1), 48-58.

Fucikovsky, L., \& Duveiller, E. (1997). Other plant pathogenic bacteria reported on wheat. In E. Duveiller, L. Fucikovsky, \& K. Rudolph (Eds.), The bacterial diseases of wheat. Concept and methods of disease management (pp. 59-64). Mexico: CIMMYT.

Hoorfar, J., Cook, N., Malorny, B., Wagner, M., De Medici, D., Abdulmawjood, A., \& Fach, P. (2003). Making internal amplification control mandatory for diagnostic PCR [2]. Journal of Clinical Microbiology, 41(12), 5835.

James, D., Varga, A., Pallas, V., \& Candresse, T. (2006). Strategies for simultaneous detection of multiple plant viruses. Canadian Journal of Plant Pathology, 28(1), 16-29.

Li, W., Teixeira, D. C., Hartung, J. S., Huang, Q., Duan, Y., Zhou, L., \& Levy, L. (2013). Development and systematic validation of qPCR assays for rapid and reliable differentiation of Xylella fastidiosa strains causing citrus variegated chlorosis. Journal of Microbiological Methods, 92(1), 79-89.

Mackay, I. M. (2004). Real-time PCR in the microbiology laboratory. Clinical Microbiology and Infection, 10(3), 190212. doi:10.1111/j.1198-743X.2004.00722.x.

Malorny, B., Paccassoni, E., Fach, P., Bunge, C., Martin, A., \& Helmuth, R. (2004). Diagnostic real-time PCR for detection of Salmonella in food. Applied and Environmental Microbiology, 70(12), 7046-7052.

Massart, S., De Clercq, D., Salmon, M., Dickburt, C., \& Jijakli, M. H. (2005). Development of real-time PCR using Minor Groove Binding probe to monitor the biological control agent Candida oleophila (strain O). Journal of Microbiological Methods, 60(1), 73-82.

Massart, S., Brostaux, Y., Barbarossa, L., César, V., Cieslinska, M., Dutrecq, O., \& Jijakli, M. H. (2008). Inter-laboratory evaluation of a duplex RT-PCR method using crude extracts for the simultaneous detection of Prune dwarf virus and Prunus necrotic ringspot virus. European Journal of Plant Pathology, 122(4), 539-547.
Mumford, R., Boonham, N., Tomlinson, J., \& Barker, I. (2006). Advances in molecular phytodiagnostics - new solutions for old problems. European Journal of Plant Pathology, 116(1), 1-19.

Ozakman, M., \& Schaad, N. W. (2003). A real-time BIO-PCR assay for detection of Ralstonia solanacearum race 3, biovar 2, in asymptomatic potato tubers. Canadian Journal of Plant Pathology, 25(3), 232-239. doi:10.1080/ 07060660309507075.

Pastrik, K. H. (2000). Detection of Clavibacter michiganensis subsp. sepedonicus in potato tubers by multiplex PCR with coamplification of host DNA. European Journal of Plant Pathology, 106(2), 155-165. doi:10.1023/A:1008736017029.

Pastrik, K. H., \& Maiss, E. (2000). Detection of Ralstonia solanacearum in potato tubers by polymerase chain reaction. Journal of Phytopathology, 148(11-12), 619-626.

Pastrik, K. H., Elphinstone, J. G., \& Pukall, R. (2002). Sequence analysis and detection of Ralstonia solanacearum by multiplex PCR amplification of 16S-23S ribosomal intergenic spacer region with internal positive control. European Journal of plant pathology/European Foundation for Plant Pathology, 108(9), 831-842.

Schaad, N. W., Berthier-Schaad, Y., Sechler, A., \& Knorr, D. (1999). Detection of Clavibacter michiganensis subsp. sepedonicus in potato tubers by BIO-PCR and an automated real-time fluorescence detection system. Plant Disease, 83(12), 1095-1100.

Seal, S., Taghavi, M., Fegan, N., Hayward, A. C., \& Fegan, M. (1999). Determination of Ralstonia (Pseudomonas) solanacearum rDNA subgroups by PCR tests. Plant Pathology, 48, 115-120. doi:10.1046/j.1365-3059.1999. 00322.x.

Van Brunschot, S. L., Gambley, C. F., De Barro, P. J., Grams, R., Thomas, J. E., Henderson, J., et al. (2013). Panel of realtime PCRs for the multiplexed detection of two tomatoinfecting begomoviruses and their cognate whitefly vector species. Plant Pathology.

Van Hoeyveld, E., Houtmeyers, F., Massonet, C., Moens, L., Van Ranst, M., Blanckaert, N., \& Bossuyt, X. (2004). Detection of single nucleotide polymorphisms in the mannosebinding lectin gene using minor groove binder-DNA probes. Journal of Immunological Methods, 287(1-2), 227-230.

Weller, S. A., Elphinstone, J. G., Smith, N. C., Boonham, N., \& Stead, D. E. (2000). Detection of Ralstonia solanacearum strains with a quantitative, multiplex, real-time, fluorogenic PCR (TaqMan) assay. Applied and Environmental Microbiology, 66(7), 2853-2858. doi:10.1128/aem.66.7. 2853-2858.2000.

Yao, Y., Nellåker, C., \& Karlsson, H. (2006). Evaluation of minor groove binding probe and TaqMan probe PCR assays: influence of mismatches and template complexity on quantification. Molecular and Cellular Probes, 20(5), 311-316.

Zielke, R., \& Naumann, K. (1984). Untersuchungen zur Erfassung des latenten Befallsstadiums von Corynebacterium sepedonicum (Spieck. et Kotth.) Skapt. et Burkh. im Kartoffelgewebe. Zentralblatt für Mikrobiologie, 139(4), 267-280. 